\title{
Research on the Deficit of China's Tourism Service Trade and Countermeasures
}

\author{
Chunfan Guo, Chuan Liao \\ Jinan University, Guangzhou, China \\ Email:123126277@qq.com
}

How to cite this paper: Guo, C.F. and Liao, C. (2017) Research on the Deficit of China's Tourism Service Trade and Countermeasures. American Journal of Industrial and Business Management, 7, 170-178. https://doi.org/10.4236/ajibm.2017.73013

Received: February 13, 2017

Accepted: March 18, 2017

Published: March 21, 2017

Copyright $\odot 2017$ by authors and Scientific Research Publishing Inc. This work is licensed under the Creative Commons Attribution International License (CC BY 4.0).

http://creativecommons.org/licenses/by/4.0/ (c) (i) Open Access

\begin{abstract}
Tourism service trade is a kind of service trade, which refers to the activities that one country or region's tourism practitioners provide service and get paid in use of the controlled tourism resources to consumers of other countries or regions. It can not only earn foreign exchange, but also promote the residents' consumption abroad. Since the reform and opening up, tourism service trade revenue has been an important source of China's trade in service. But the deficit of China's tourism service trade reached $\$ 113.6$ billion, accounting $57.7 \%$ of the service trade deficit. With the Chinese tourism service trade deficit ballooning in size, based on the fact of tourism service trade deficit, this article systematically analyzes what causes the deficit from the perspective of the international trade. In the last of this paper, some suggestions, such as governmental macroeconomic regulation and control, modest relaxation of the lens into the visa caliber, ensuring the stability of the overall price and the RMB exchange rate, optimization of the international tourism enterprises and products, optimization of the structure of China's tourism service trade, are brought forward.
\end{abstract}

\section{Keywords}

Tourism Service Trade Deficit, Outbound Tourism, Inbound Tourism

\section{Introduction}

Tourism service trade is a kind of service trade, which refers to the activities that one country or region's tourism practitioners provide service and get paid in use of the controlled tourism resources to consumers of other countries or regions [1]. At present, the tourism industry is an important pillar industry in China, tourism service trade has always been an important source of China's service trade income. However, China's tourism service trade deficit occurred for the first time in 2009, and continued to expand. As to 2014, the deficit widened to $\$ 113.6$ bil- 
lion, sharing $57.7 \%$ of the service trade deficit. Although to some extent, the tourism trade deficit alleviates the relations between China and the other countries, the long-term deficit will also harm the interests of the country [2]. In this paper, the data comes in large part from "Tourism Statistic Yearbook of China" [3] and China's National Bureau of Statistics, which are used to analyze the deficit of China's tourism service trade.

\section{Status Quo of the China's Tourism Service Trade}

\subsection{Overall Trend: Surplus Transferring to Deficit and the Deficit Expanding}

In general, the overall scale of China's tourism service trade rose sharply. Before 2008, China's tourism service trade, as one of the only two trades in services which is in state of surplus in China, played an important role in increasing foreign exchange income and balancing the international payments. The tourism service trade surplus has been partly offset China's trade deficit for many years, only in 2003 the amount of tourism service trade decreased due to the epidemic of SARS. After the year of 2009, the deficit of China's tourism service trade occurred and to extend of 2.3 billion, the size of the deficit was also in rapid growth (see Figure 1).

\subsection{The Growth of China's Outbound Tourism Service Trade Is Slowing down}

Due to the financial crisis and other factors, the global economy continued to slump since 2008. China's inbound tourism slowed down significantly. The number of China's inbound tourists and the inbound tourism foreign exchange earnings are significantly reduced (see Table 1). As we can see in Table 1, the year of 2008

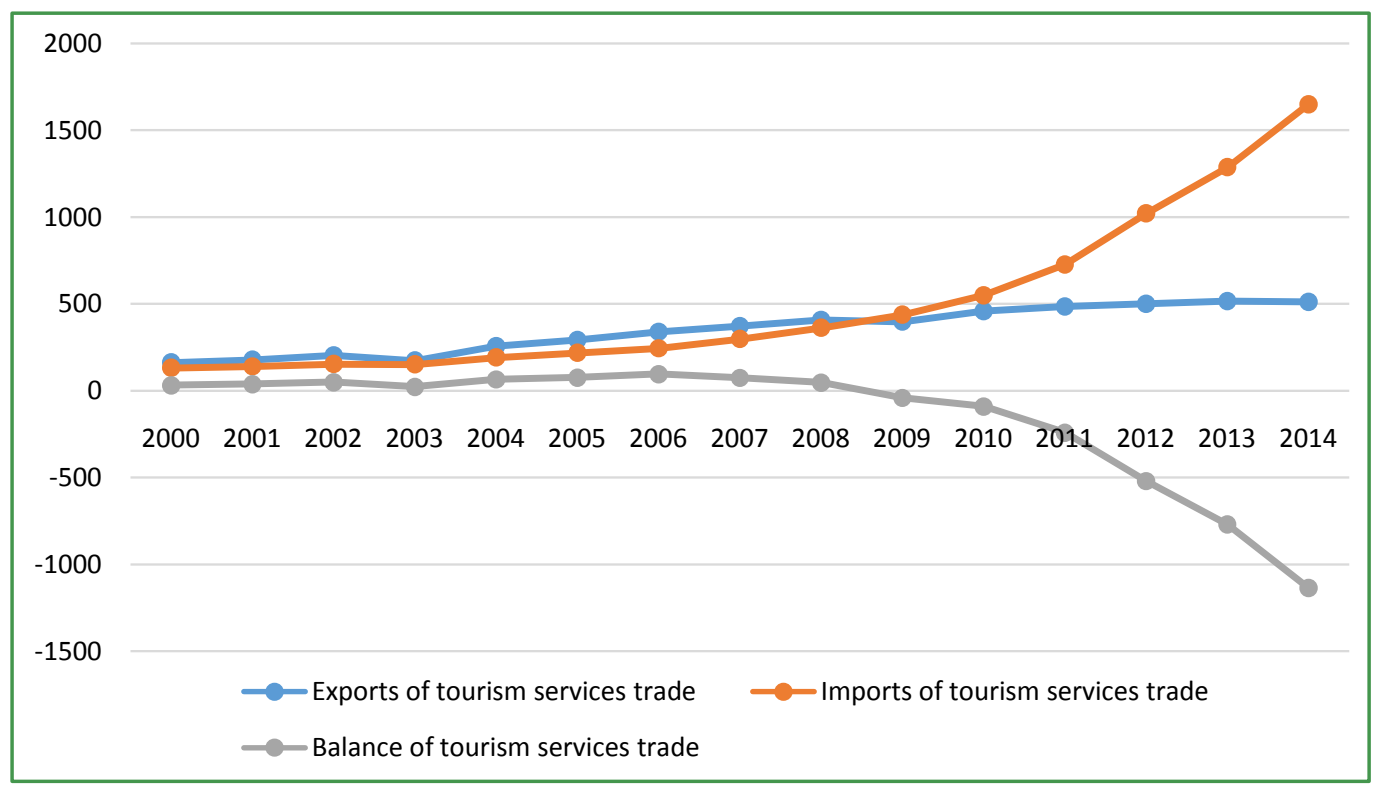

Figure 1. Import, export and balance of China's tourism service trade. Source: Tourism Statistic Yearbook of China 2016. 
Table 1. Inbound tourism of China from 2000 to 2014.

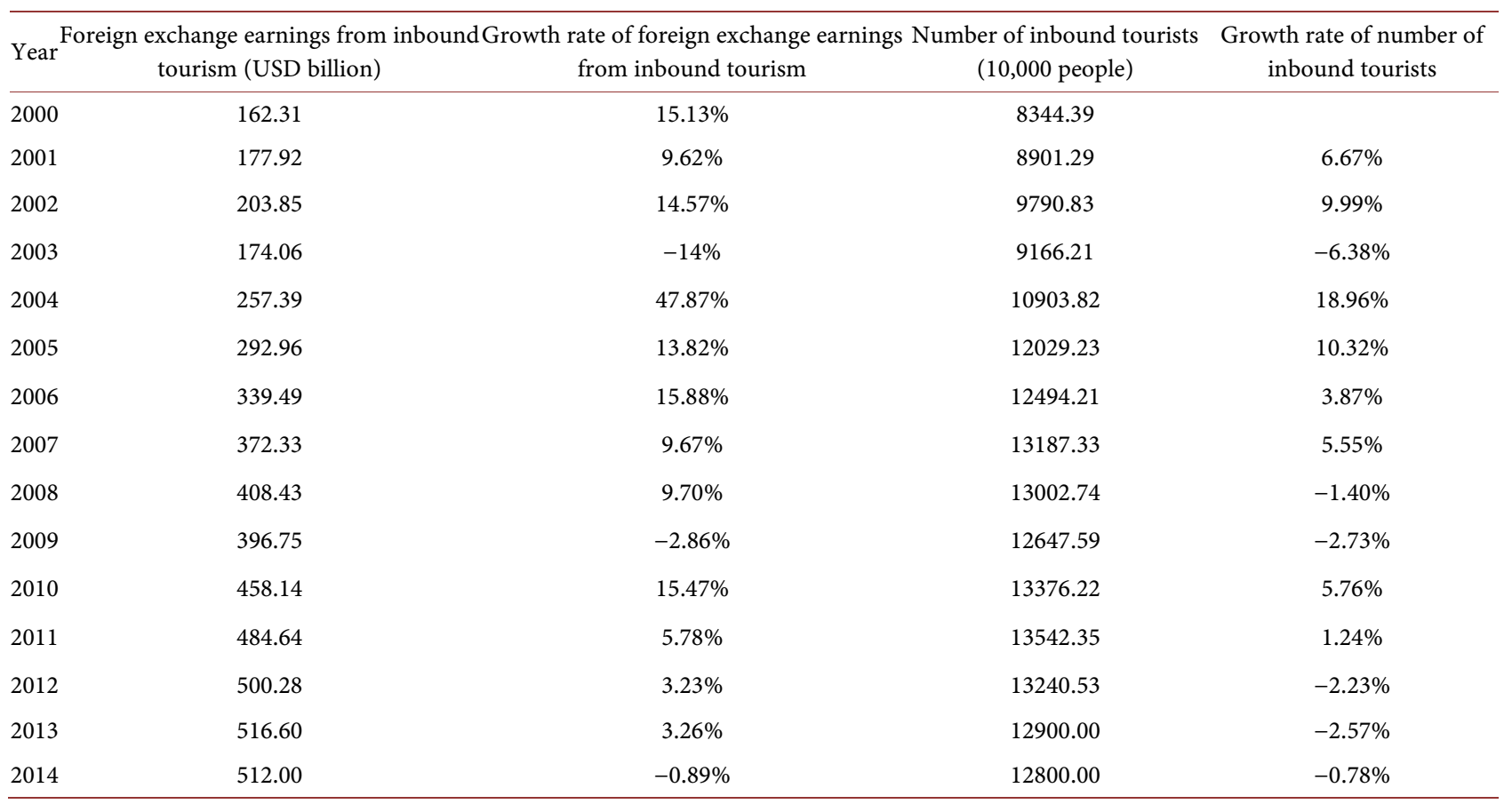

Source: Tourism Statistic Yearbook of China 2016.

is a watershed. Prior to 2008, the number of China's inbound tourists and the amount of the inbound tourism foreign exchange revenue had maintained a relatively stable growth trend (besides the year of 2003 SARS). After 2008, the number of China's inbound tourists showed a sustained negative growth in addition to 2010 and 2011, until now there are no signs of recovery.

\subsection{The Growth Rate of China's Inbound Tourism Service Trade Is Increased}

China released "Interim Measures for the administration of Chinese citizens traveling abroad" in 1997, henceforth Chinese citizens travel abroad at their own expense officially started. Since the new century, with the continuous improvement of people's living standards and the rapid development of the national economy, the growth rate of outbound tourism enlarged significantly (see Table 2). After 2009 , outbound tourism spending and the number of outbound tourists increased by an average annual rate of $28.2 \%$ and $16.62 \%$. In 2012, China's outbound tourism market had exceeded Germany and the United States, becoming the world's largest outbound tourism market.

\section{Analysis of the Causes of China's Tourism Service Trade Deficit}

\subsection{National Politics' Positive Impacts on Outbound Tourism}

The State Council approved "A report on some problems of the current tourism system reform" in 1985, which proposed that the focus only on international tourism will be turned into international and domestic tourism. Two-day weekend 
Table 2. Imports of China's tourism service trade from 2000 to 2014.

\begin{tabular}{lcccc}
\hline Year & $\begin{array}{c}\text { Expenditure on outbound tourism } \\
\text { (USD billion) }\end{array}$ & $\begin{array}{c}\text { Growth Rate of expenditure on } \\
\text { outbound tourism }\end{array}$ & $\begin{array}{c}\text { Number of outbound tourists } \\
(10,000 \text { people) }\end{array}$ & $\begin{array}{c}\text { Growth rate of number } \\
\text { of outbound tourists }\end{array}$ \\
\hline 2000 & 162.31 & $15.13 \%$ & 1047.26 & $15.86 \%$ \\
2001 & 177.92 & $9.62 \%$ & 1213.31 & $36.83 \%$ \\
2002 & 203.85 & $14.57 \%$ & 1660.23 & $21.80 \%$ \\
2003 & 174.06 & $-14 \%$ & 2022.19 & $42.68 \%$ \\
2004 & 257.39 & $47.87 \%$ & 2885.29 & $7.55 \%$ \\
2005 & 292.96 & $13.82 \%$ & 3103.00 & $11.26 \%$ \\
2006 & 339.49 & $15.88 \%$ & 3452.36 & $18.63 \%$ \\
2007 & 372.33 & $9.67 \%$ & 4095.40 & $11.94 \%$ \\
2008 & 408.43 & $9.70 \%$ & 4584.44 & $3.95 \%$ \\
2009 & 396.75 & $-2.86 \%$ & 4765.63 & $20.42 \%$ \\
2010 & 458.14 & $15.47 \%$ & 5739.00 & $22.41 \%$ \\
2011 & 484.64 & $5.78 \%$ & 7025.00 & $18.41 \%$ \\
2012 & 500.28 & $3.23 \%$ & 8318.27 & $18.04 \%$ \\
2013 & 516.60 & $3.26 \%$ & 9818.52 & $11.01 \%$ \\
2014 & 512.00 & $-0.89 \%$ & 10900.00 & \\
\hline
\end{tabular}

Source: Tourism Statistic Yearbook of China 2016.

system put into practice in 1993, the same year the State Council forwarded "opinions on actively developing domestic tourism" from the National Tourism Bureau, which marked the official start of domestic tourism [4]. Subsequently, the golden holiday system was implemented in 1999; people have more and more leisure time to travel abroad. $2005 \mathrm{RMB}$ exchange rate formation mechanism reform, the RMB began to appreciate, the cost to of outbound tourism continued to decline. In November 2009, the executive meeting of the State Council formulated and published the "views on accelerating the development of tourism", which proposed "to cultivate tourism as a strategic pillar industry of the national economy and satisfactory modern service industry for people". Affected by the policy and the development of China's tourism industry, many countries have begun to actively cooperate with China. By September 2014, more than 151 countries and regions signed bilateral agreements on tourism with China, allowing China tourists to travel in their country in the form of a team at their own expense. In recent years, the government introduced a series of policies to guide the national tourism consumption, driving the development of domestic tourism and outbound tourism market.

\subsection{The Rapid Development of the Domestic Economy to Promote Outbound Tourism}

According to the website of the National Bureau of statistics data, the per capita net income of rural residents is up to 11,422 yuan in 2015 increased from 4761 yuan in 2008, excluding the price factor, the actual annual growth rate (year-on-year) maintained above $8.4 \%$; over the same period, per capita disposable income of 
urban residents increased to 31,195 yuan from 15,781 yuan, excluding the price factor. The actual growth rate (year-on-year) remain above $7 \%$ (see Table 3 ). From the development of global tourism destination, the motivation of tourists enhance with per capita GDP growth: when per capita GDP reached 400 U.S. dollars, the residents will have the motivation of domestic tourism; when the per capita GDP reached 1000 U.S. dollars, the residents will have the motivation to go to neighboring tourism; when the GDP per capita worth more than $\$ 3000$, the residents will have intercontinental travel motivation [5]. The growth of the income of residents is an important factor to promote domestic consumers to pursue higher tourism service requirements. In order to avoid the crowded situation of domestic tourism market, they choose to travel abroad.

\subsection{Rising Domestic Prices and the Appreciation of the RMB [6]}

Statistics data of China's National Bureau shows that the CPI index of 2010-2014 was $536.1,565,579.7,606.7,522.7(1978=100)$, an average annual increase is about $4 \%$. From an economic point of view, inbound tourism is not an ordinary, basic consumer activity, but a higher level of consumer activity, so that the absolute value of the price elasticity coefficient of tourism demand is generally bigger than 1 . The increase of tourism price will lead to a sharp decline in the demand for inbound tourism, the tourism revenue will also decline; on the contrary, the decline in prices will lead to a surge in demand, and the inbound tourism revenue will be effectively improved [7]. Therefore, the price increases the price advantage of domestic tourism products is no longer obvious, the cost of tourism is still increasing, making more and more people choose to travel aboard.

At the same time, the RMB against the U.S. dollar drops to about 1:6.6 in 2015 from 1:8.2 in 2004, the RMB appreciation is about 25\% (see Table 4). For domestic residents, $\mathrm{RMB}$ appreciation means the relative enhancement of purchasing power

Table 3. Per capita disposable income of urban and rural residents in China. Unit: yuan.

\begin{tabular}{ccccccccc}
\hline Year & \multicolumn{2}{c}{2008} & \multicolumn{2}{c}{2009} & \multicolumn{2}{c}{2010} & 2011 \\
\hline Index & Rural & Urban & Rural & Urban & Rural & Urban & Rural & Urban \\
\hline Income & 4761 & 15,781 & 5153 & 17,175 & 5919 & 19,109 & 6977 & 21,810 \\
Growth rate of income & 8.4 & 8.0 & 8.5 & 9.8 & 10.9 & 7.8 & 11.5 & 8.4 \\
\hline Year & 2012 & 2013 & 2014 & 2015 \\
\hline Index & Rural & Urban & Rural & Urban & Rural & Urban & Rural & Urban \\
\hline Income & 7917 & 24,565 & 8896 & 26,955 & 10,489 & 28,844 & 11,422 & 31,195 \\
Growth rate of income & 10.7 & 9.6 & 9.3 & 7.0 & 11.2 & 9.0 & 8.9 & 8.2 \\
\hline
\end{tabular}

Source: China's National Bureau of Statistics.

Table 4. Changes in the exchange rate of the RMB against the US Dollar.

\begin{tabular}{ccccccccccccc}
\hline Year & 2004 & 2005 & 2006 & 2007 & 2008 & 2009 & 2010 & 2011 & 2012 & 2013 & 2014 & 2015 \\
\hline Exchange rate & 8.28 & 8.10 & 7.81 & 7.39 & 6.85 & 6.81 & 6.62 & 6.48 & 6.37 & 6.13 & 6.24 & 6.60 \\
\hline
\end{tabular}

Source: China's National Bureau of Statistics. 
in the foreign country, outbound tourism price becomes cheaper, overseas consumption demand will continue to increase. On the contrary, for foreign tourists, the appreciation of the RMB means that the relative devaluation of the domestic currency, inbound tourism demand will be affected [8].

\subsection{China's Tourism Service Trade's Low Competitiveness}

The tourism service trade statistics is difficult to unity, we usually adopt the measure tool of international competitiveness of the first American economist Barra$\mathrm{za}$ - the revealed comparative advantage index (RCA), this index can accurately reflect the comparative advantage in the import and export trade of a country, when $\mathrm{RCA}<0.8$, the regional service trade competitiveness is weak; when $0.8<\mathrm{RCA}<$ 1 , then it shows that the competitiveness of the regional service trade is low; 0.8 $<\mathrm{RCA}<1.25$, it shoes that the regional service trade has moderate competitiveness in the international market: when $1.25<\mathrm{RCA}<2.5$, the regional service trade competitiveness; when RCA $>2.5$, international competitiveness is strong. The value of RCA of China declined since 2008 (see Table 5), which shows that the level of international competitiveness is not stable, although China is a large outbound country, but it does not belong to the tourism service trade.

\subsection{The Tourism Product Structure Is Single, and the High Quality Service Is Provided by the Foreign Tourism Destinations}

The structure of our country's tourism products mainly because of the simple brand, such as the lack of tourism resources publicity in the international tourism brand competition, the lack of traditional tourism scenic spots and cultural connotation of scenic area propaganda, the low level of artificial landscape, the phenomenon of repeated construction of the near distance, lack of strong attraction to tourists. In contrast to many tourist attractions of foreign country of providing high quality tourism services to attract Chinese tourists, such as through department stores, shopping outlets of South Korea and other famous attractions specifically to attract high-end consumer Chinese women, opening a super luxury accommodation shopping-delicacy beauty etc. all in one service; In 2015 Germany launched the theme of "business travel" and "smart travel". The found more and more China talents and discuss with these professionals; France launched the romantic honeymoon, wine related tourism products to attract Chinese tourists who are interested in French wine. It can be seen that the structure of China's tourism service trade is relatively simple, and there are some deficiencies in the exploration of different tourism needs of different tourists.

Table 5. The displaying comparative advantage index of China's tourism service trade from 2000 to 2015.

\begin{tabular}{cccccccccccccccccc}
\hline Year & 2000 & 2001 & 2002 & 2003 & 2004 & 2005 & 2006 & 2007 & 2008 & 2009 & 2010 & 2011 & 2012 & 2013 & 2014 & 2015 \\
\hline Index & 0.97 & 0.99 & 0.64 & 0.07 & 0.70 & 0.7 & 0.63 & 0.57 & 0.53 & 0.55 & 0.51 & 0.5 & 0.5 & 0.48 & 0.47 & 0.47 \\
\hline
\end{tabular}

Source: China's National Bureau of Statistics. 


\subsection{Poor Environment Has a Negative Impact on Inbound Tourism}

In recent years, the large scope of our country haze weather scared many tourists, "The 2014 Chinese inbound tourism development annual report" pointed out that in 2013 the number of foreign tourists is about 129 million, decreased about 2.51\%; the number of inbound overnight tourists is about 55 million, a decrease of $3.53 \%$ compared to the same period, the bad weather of haze is one of the main cause. In addition, our country's poor consumer environment and the proliferation of fakes are also leading to the country's outbound shopping entertainment and foreign tourists' low consumption in China.

\section{Countermeasures and Suggestions to Get out of the Plight of Deficit of Tourism Services Trade}

\subsection{Macro-Control by Government to Guide the Development of Tourism Industry}

First of all, government should develop a strategy-oriented tourism policy, and strengthen the direction and long-term effect in developing inbounding tourism market, to achieve the change of inbound tourism from the emphasis on "quantity" growth to "quality and quantity" and co-ordinate the development of inbound tourism industry. Secondly, government should establish and improve the tourism legal system, issue policies on the level of nation to support tourism service trade, regulate and guide the tourism business behavior, such as the "Tourism Law" issued in 2013, which contributes to regulate the behavior of tourism operators, protect tourists rights, and provide a solid legal basis and policy support for the development of inbound tourism. Thirdly, construction of tourism pillar industry and industrial chain should be strengthened, such as transportation, hotel and information industry, which constitute main expenditure of inbound tourists. Specifically, government should increase international routes, perfect e-commerce system of inbound tourism reservation, improve the financial services system of credit card payment.

\subsection{Relax the Visa Caliber Appropriately, Take Measures to Control Outbound Tourism}

With the rapid development of China's outbound tourism, some foreign countries and regions moderately relaxed entry visa procedures in order to attract Chinese citizens, outbound tourism. There are already 17 countries which achieve a real sense of the visa-free or landing visa with China. We can reach a cooperation agreement with more tourism regions learning from these experiences, and improve the policy of shopping departure tax rebate and tariff reduction for foreign tourists. In the future, government can cooperate with South Korea and Japan in opening up new tourist routes, in the name of "Maritime Silk Road", which will attract more foreign tourists. At the same time, government should take appropriate control measures of the outbound tourism to prevent tourism trade deficit continuously expanding. China is already the largest trade deficit country in the world. As an important part of China's service trade, 
tourism service trade should make due contribution to narrowing the deficit of trade in services, For example, government could collect taxation or other economic means to properly control China's outbound tourism, so that preventing excessive trade deficit in tourism services as well as promoting the development of inbound tourism.

\subsection{Maintain the Overall Level of Price and the RMB Exchange Rate Relatively Stable}

China's per capita disposable income of urban residents is increasing. At the same time, the overall price level is also rising. A few years ago, China's currency circulation, agricultural production costs, hot money speculation and other factors make prices soar too fast, which weakens the real purchasing power of the yuan in the hands of tourists. Therefore, government should implement a prudent monetary policy and other measures to stabilize prices. At the same time, the RMB exchange rate should remain relatively stable. The continuous appreciation of the RMB has made a greater negative impact of inbound tourism since 2000. Therefore, maintaining domestic price stable and the relative stability of the RMB exchange rate will play a greater stimulating effect on China's inbound tourism consumption.

\subsection{Optimize the International Tourism Enterprises and Products [9], Improve the Competitiveness of China's Tourism Service Trade}

China is rich in natural tourism resources and cultural tourism resources, which is unmatched to other countries. However, China's tourism products are relatively simple, which are mainly for sightseeing and leisure. To improve the competitiveness of China's tourism market, China's tourism sector and tourism enterprises should develop marketable tourism products for their respective target markets, to maintain their characteristics on the basis of their diversity. At the same time, China's tourism industry presents a "scattered, small, weak and poor" situation. Most of China's tourism enterprises pursue quick success and lack humanistic care. Therefore, the tourism enterprise should reform enterprise internal system. They must find out their advantages, opportunities in the entire tourism market, and recognize their own weaknesses, threats. In the service, tourism enterprise should regard "customer is God" as the highest purpose of serving to provide their own competitiveness. In addition, we can establish the image of our tourism products through "Internet+" and other platforms, and then formulate corresponding products and marketing programs so as to build unique tourism brands and enhance the core competitiveness of China's tourism.

\subsection{Optimize the Structure of China's Tourism Service Trade, Improve the Related Infrastructure System}

There is a serious imbalance phenomenon of the export structure of China's tourism service trade. Transportation accounts for evenly more than 55\%, which is the most important component of tourism service trade. As China has a long history 
and vast territory, a large number of cultural relics and scenic spots locate throughout the country. If inbound tourists want to visit a number of attractions in a limited time, they will select to travel by long-distance transport, which results in a high proportion of transportation. Commodity sales, accommodation and catering, followed by transportation, are also the main spending of inbound tourism consumption, while the posts and telecommunications, entertainment, tour account for small proportion, which is related to China's long-term policy deflection in the tourism product structure. Therefore, China should vigorously develop the production and sale of tourism products when paying attention to construction of tourism destination, travel agencies and hotels.

\subsection{Improve Environmental Awareness, Establish Good Tourist Environment}

China has a large number of tourism resources and attractions; however, China usually carries out tourism activities in the way of consuming resources, which leads to the destruction of China's tourism resources. At the same time, haze and other environmental factors have also caused a great impact on inbound tourism. Generally speaking, inbound tourists prefer Beijing, capital of China, as their destinations. While Beijing's environmental pollution is very serious, the amount of tourists has been declining. In addition, some uncivilized behaviors, such as litter, spitting, loud noises, affect the image of China's tourism in a large extent. Therefore, government should not only strengthen the protection of tourism resources, but also guide the citizens to improve environmental awareness to jointly establish a good tourist environment.

\section{References}

[1] He, Y.G. and Hu, X.Y. (2014) Real Effective Exchange Rate and "Word of Mouth": Illustration of Tourism Service Trade in Canada. Journal of Guizhou College of Finance and Economics, 3, 74-81.

[2] Katircioglu, S.T. (2009) Tourism, Trade, and Growth: The Case of Cyorus. Applied Economics, 41, 2741-2750. https://doi.org/10.1080/00036840701335512

[3] CSY (2016) China Statistical Yearbook. China Statistical Publishing House, Beijing.

[4] Li, Z.G. (2012) The Status Quo, Causes and Countermeasures of Imbalance of Tourism Service Trade in China. Commercial Times, 14, 58-59.

[5] Oh, C. (2005) The Contribution of Tourism Development to Economic Growth in the Korean Economy. Tourism Management, 26, 39-44. https://doi.org/10.1016/j.tourman.2003.09.014

[6] Wang, X.H. and Wu, Z.H. (2016) Research on Trade Deficit of China's Tourism Service. Prices Monthly, 1, 31-37.

[7] Seetanah, B. (2011) Assessing the Dynamic Economic Impact of Tourism for Island Economies. Annals of Tourism Research, 38, 291-308. https://doi.org/10.1016/j.annals.2010.08.009

[8] Kulendran, N. and Wilson, K. (2000) Is There a Relationship between International Trade and International Travel. Applied Economics, 32, 1001-1009. https://doi.org/10.1080/000368400322057

[9] Liang, Q. (1999) Impacts and Countermeasures of Asian Financial Crisis on International Tourism Service Trade. Journal of International Trade, 1, 22-26. 
Submit or recommend next manuscript to SCIRP and we will provide best service for you:

Accepting pre-submission inquiries through Email, Facebook, LinkedIn, Twitter, etc. A wide selection of journals (inclusive of 9 subjects, more than 200 journals)

Providing 24-hour high-quality service

User-friendly online submission system

Fair and swift peer-review system

Efficient typesetting and proofreading procedure

Display of the result of downloads and visits, as well as the number of cited articles Maximum dissemination of your research work

Submit your manuscript at: http://papersubmission.scirp.org/

Or contact ajibm@scirp.org 